\title{
Isolation and characterization of a novel 2-sec-butylphenol-degrading bacterium Pseudomonas sp. strain MS-1
}

\author{
Tadashi Toyama $\cdot$ Noritaka Maeda $\cdot$ \\ Manabu Murashita - Yong-Cheol Chang · \\ Shintaro Kikuchi
}

Received: 15 May 2009/Accepted: 5 August 2009/Published online: 25 August 2009

(C) The Author(s) 2009. This article is published with open access at Springerlink.com

\begin{abstract}
A novel bacterium capable of utilizing 2-sec-butylphenol as the sole carbon and energy source, Pseudomonas sp. strain MS-1, was isolated from freshwater sediment. Within $30 \mathrm{~h}$, strain MS-1 completely degraded $1.5 \mathrm{mM}$ 2-sec-butylphenol in basal salt medium, with concomitant cell growth. A pathway for the metabolism of 2-sec-butylphenol by strain MS-1 was proposed on the basis of the identification of 3 internal metabolites-3-sec-butylcatechol, 2-hydroxy6-oxo-7-methylnona-2,4-dienoic acid, and 2-methylbutyric acid-by gas chromatography-mass spectrometry analysis. Strain MS-1 degraded 2-sec-butylphenol through 3-sec-butylcatechol along a meta-cleavage pathway. Degradation experiments with various alkylphenols showed that the degradability of alkylphenols by strain MS-1 depended strongly on the position (ortho $\gg m e t a=$ para) of the alkyl substitute, and that strain MS-1 could degrade 2-alkylphenols with various sized and branched alkyl chain (o-cresol, 2-ethylphenol, 2-n-propylphenol, 2-isopropylphenol, 2-sec-butylphenol, and 2-tert-butylphenol), as well as a dialkylphenol (namely, 6-tert-butyl-m-cresol).
\end{abstract}

T. Toyama $(\bowtie) \cdot$ N. Maeda $\cdot$ M. Murashita .

Y.-C. Chang - S. Kikuchi

Division of Applied Sciences, Muroran Institute of Technology, 27-1 Mizumoto, Muroran 050-8585, Japan

e-mail: tadashi@mmm.muroran-it.ac.jp
Keywords 2-sec-Butylphenol · ortho-Substituted alkylphenol · Biodegradation · meta-Cleavage pathway

\section{Introduction}

Alkylphenols, a group of chemical compounds that consist of a phenol with an alkyl chain, are ubiquitous pollutants in urban aquatic environments. Alkylphenols are industrially important chemicals and are abundantly and widely used to produce alkylphenol polyethoxylates and phenolic resins (McLeese et al. 1981; Ying et al. 2002). Furthermore, alkylphenols with an alkyl chain longer than 3 carbon atoms $(\geq \mathrm{C} 3)$ interact with estrogen receptors (Hu and Aizawa 2003; Routledge and Sumpter 1997; Tollefsen et al. 2008; White et al. 1994) and have other toxic effects on aquatic organisms and humans (Mcleese et al. 1981; Servos 1999). Therefore, considerable attention has been paid to their environmental fates and biodegradabilities.

Studies of the biodegradation of alkylphenols have focused mainly on para-substituted alkylphenols, including 4-nonylphenol, 4-octylphenol, and 4-alkylphenol with medium-length alkyl chains (C3 to C7). Several sphingomonads, including Sphingomonas sp. strain TTNP3 (Tanghe et al. 1999), Sphingobium xenophagum Bayram (Gabriel et al. 2005), and Sphingomonas cloacae (Fujii et al. 2001), have recently been isolated from activated sludge; these sphingomonads 
can degrade branched 4-nonylphenol and utilize it as a sole carbon source. In addition, several Pseudomonas strains that can degrade medium-length 4- $n$-alkylphenol and utilize it as a sole carbon source, including Pseudomonas sp. KL28 (Jeong et al. 2003), Pseudomonas putida MT4 (Takeo et al. 2006), and Pseudomonas veronii INA06 (Ajithkumar et al. 2003), have been isolated from activated sludge or contaminated soil. In contrast, there has been only one previously reported bacterial strain capable of degrading ortho-substituted alkylphenols (2-alkylphenols) with an alkyl chain of $\geq \mathrm{C} 3$, including 2-n-propylphenol, 2-isopropylphenol, and 2-sec-butylphenol; namely, Pseudomonas azelaica HBP1 Prp (Kohler et al. 1993; Reichlin and Kohler 1994; van der Maarel and Kohler 1993), which is a regulatory mutant that grows on 2-propylphenol and 2sec-butylphenol. The wild-type strain HBP1 cannot grow on 2-alkylphenol (Kohler et al. 1993).

Therefore, it remains unclear which bacteria can degrade 2-alkylphenols and how this biodegradation occurs in the natural aquatic environment. Because 2-alkylphenols with an alkyl chain of $\geq \mathrm{C} 3$, including 2-propylphenols and 2-butylphenols, exhibit estrogenic activity (Hu and Aizawa 2003; Routledge and Sumpter 1997; Tollefsen et al. 2008) and other toxic effects (Acuña-Argüelles et al. 2003; Choi et al. 2004; $\mathrm{Li}$ et al. 2008), it is important to understand their fates and biodegradation in the aquatic environment.

Here we report the characterization of Pseudomonas sp. strain MS-1 isolated from a natural freshwater sediment. The strain was capable of utilizing 2-secbutylphenol as the sole carbon source.

\section{Materials and methods}

\section{Chemicals}

Phenol, $o$-cresol, $m$-cresol, $p$-cresol, 2-ethylphenol, 3-ethylphenol, 4-ethylphenol, 2- $n$-propylphenol, 2-isopropylphenol, 3-isopropylphenol, 4-n-propylphenol, 4isopropylphenol, 2-sec-butylphenol, 2-tert-butylphenol, 3-tert-butylphenol, 4- $n$-butylphenol, 4-sec-butylphenol, 4-tert-butylphenol, 2,4-di-tert-butylphenol, 2,6-di-tertbutylphenol, 6-tert-butyl- $m$-cresol, and $N, O$-bis(trimethylsilyl)trifluoroacetamide (BSTFA) were purchased from Tokyo Chemical Industry (Tokyo, Japan). 2Methylbutyric acid was purchased from Acros Organics (Morris Plains, New Jersey, USA).
Culture media

Basal salts medium (BSM) (Toyama et al. 2009) was used for degradation tests, and BSM containing 2sec-butylphenol (2sBP-BSM) as the sole carbon source was used for culture of 2-sec-butylphenoldegrading bacteria. Agar solid medium was prepared with $2.0 \%(w / v)$ agar.

Enrichment, isolation, and identification of 2-sec-butylphenol-degrading bacteria

A sediment sample was obtained from within Phragmites australis (reed) zone in Inukai Pond at Osaka University, Suita, Osaka, Japan. The sediment sample was collected from about $20 \mathrm{~cm}$ sediment depth, around the plant roots. Detailed physicochemical analysis revealed that the sediment sample had a $\mathrm{pH}$ of 6.9, a low organic carbon content (ignition loss = $2.2 \%$ ), and no alkylphenols (2-sec-butylphenol, 4- $n$ butylphenol, 4-tert-butylphenol, 4-tert-octylphenol, or nonylphenol). Enrichment of 2-sec-butylphenoldegrading bacteria from the sediment was performed by transferring $1 \mathrm{~g}$ of sediment sample to a $300-\mathrm{ml}$ flask containing $100 \mathrm{ml} \mathrm{2sBP-BSM}(0.5 \mathrm{mM})$. The mixture was incubated at $28^{\circ} \mathrm{C}$ on a rotary shaker at $120 \mathrm{rpm}$ for 14 days. We then transferred $1 \mathrm{ml}$ of the culture of sediment to fresh 2sBP-BSM $(0.5 \mathrm{mM})$. After third transfers, the enrichment culture was serially diluted and spread on 2sBP-BSM $(0.5 \mathrm{mM})$ agar plates, and the plants were incubated at $28^{\circ} \mathrm{C}$. The isolated bacterial strain, designated MS-1, was characterized and identified by physiological and phylogenetic analyses (Inoue et al. 2008).

Growth and degradation experiments

Strain MS-1 was grown overnight in 2sBP-BSM $(1.0 \mathrm{mM})$. Cells were harvested by centrifugation $\left(9,600 \mathrm{~g}, 4^{\circ} \mathrm{C}, 10 \mathrm{~min}\right)$, washed twice with $50 \mathrm{mM}$ potassium phosphate buffer ( $\mathrm{pH} 7.5$ ), and inoculated at a cell density of 0.02 (i.e., optical density at a wavelength of $\left.600 \mathrm{~nm}\left[\mathrm{OD}_{600}\right]=0.02\right)$ into $2 \mathrm{sBP}-\mathrm{BSM}(1.5 \mathrm{mM})$. Also, the cells were inoculated at an $\mathrm{OD}_{600}$ of 0.02 into BSM containing $1.5 \mathrm{mM}$ 2-methylbutyric acid as the sole carbon source. Cultivation was carried out at $28^{\circ} \mathrm{C}$ and $120 \mathrm{rpm}$. Cell densities, concentrations of 2-secbutylphenol and 2-methylbutyric acid, and metabolites 
produced by 2-sec-butylphenol degradation were monitored periodically over the 48-h experimental period.

Alkylphenols with alkyl chains of various sizes, branches, and positions were used for growth experiments on strain MS-1 and for degradation tests using whole-cell strain MS-1. Cells, prepared as described above, were added at an $\mathrm{OD}_{600}$ of 0.02 (in the growth experiments) or 0.5 (in the degradation tests) to BSM supplemented with the following alkylphenols as the sole carbon source at $0.5 \mathrm{mM}$ : phenol, $o$-cresol, $m$ cresol, $p$-cresol, 2-ethylphenol, 3-ethylphenol, 4-ethylphenol, 2-n-propylphenol, 2-isopropylphenol, 3-isopropylphenol, 4-n-propylphenol, 4-isopropylphenol, 2-sec-butylphenol, 2-tert-butylphenol, 3tert-butylphenol, 4- $n$-butylphenol, 4-sec-butylphenol, 4-tert-butylphenol, 2,4-di-tert-butylphenol, 2,6-ditert-butylphenol, and 6-tert-butyl-m-cresol. Cultivation was performed as $28^{\circ} \mathrm{C}$ and $120 \mathrm{rpm}$. Cell densities and substrate concentrations were monitored every $12 \mathrm{~h}$ over the 48 -h experimental period.

\section{Analytical procedures}

Bacterial growth was monitored by recording $\mathrm{OD}_{600}$, and the dry weight of the cells was determined. The cells were harvested by centrifugation $\left(9,600 \mathrm{~g}, 4^{\circ} \mathrm{C}\right.$, $10 \mathrm{~min}$ ) and washed twice with $50 \mathrm{mM}$ potassium phosphate buffer ( $\mathrm{pH} 7.5$ ), and the cell suspension was filtered through a pre-weighed filter (pore size $0.2 \mu \mathrm{m}$, polycarbonate; Millipore, Tokyo, Japan). The filter, together with the cells, was dried at $90^{\circ} \mathrm{C}$ for $3 \mathrm{~h}$ before weighing. Alkylphenol concentrations were determined by high-performance liquid chromatography (HPLC); the 2-methylbutyric acid concentration was determined by gas chromatography-mass spectrometry (GC-MS); and metabolites of 2-sec-butylphenol were analyzed by GC-MS. For the HPLC and GC-MS analyses, the collected culture was acidified with $1 \mathrm{~N}$ $\mathrm{HCl}$, shaken for 3 min with an equal volume of $1: 1$ (v:v) ethyl acetate: $n$-hexane, and centrifuged $(9,600 g$, $\left.4^{\circ} \mathrm{C}, 10 \mathrm{~min}\right)$; the organic layer was then extracted. The extract was directly analyzed by HPLC and GCMS. Also, for GC-MS analysis of metabolites produced by 2-sec-butylphenol degradation, the extract was dried under a nitrogen flow and subjected to trimethylsilylation (TMS) using a BSTFA-acetonitrile solution at $60^{\circ} \mathrm{C}$ for $1 \mathrm{~h}$. The HPLC analysis was conducted with a Shimadzu HPLC system with an SPD-10AV UV-vis detector and a Shim-pack
VP-ODS column $(4.5 \times 150 \mathrm{~mm}$, particle size $5 \mu \mathrm{m}$; Shimadzu, Kyoto, Japan). In the HPLC analysis, 8:2 (v:v) acetonitrile:water was used as a mobile phase, and the detection wavelength was $277 \mathrm{~nm}$. The GCMS analysis was conducted with a Shimadzu GC/MS system (GCMS-QP2010) and an Rxi-5 ms capillary column (30 m, $0.25 \mathrm{~mm}$ ID, $1.00 \mu \mathrm{m} d f$; Restek, Pennsylvania, USA). In the GC-MS analysis, the column temperature programs were as follows: (i) hold

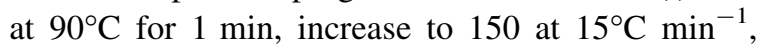
increase to $300^{\circ} \mathrm{C}$ at $5^{\circ} \mathrm{C} \mathrm{min}{ }^{-1}$, and hold at $300^{\circ} \mathrm{C}$ for 5 min for analysis of metabolites with TMS derivatization; and (ii) hold at $60^{\circ} \mathrm{C}$ for $2 \mathrm{~min}$, increase to $300^{\circ} \mathrm{C}$ at $20^{\circ} \mathrm{C} \mathrm{min}^{-1}$, and hold at $300^{\circ} \mathrm{C}$ for $5 \mathrm{~min}$ for analysis of metabolites without TMS derivatization. The injection, interface, and ion-source temperatures were 280,280 , and $250^{\circ} \mathrm{C}$, respectively. Helium $(99.995 \%)$ was used as the carrier gas at a flow rate of $1.0 \mathrm{ml} \mathrm{min}{ }^{-1}$.

Nucleotide sequence accession number

The 16S rRNA gene sequence of strain MS-1 has been submitted to the DDBJ/EMBL/GenBank databases under accession no. AB499847.

\section{Results}

Isolation and identification of 2-sec-butylphenoldegrading bacteria

The sediment sample was incubated in 2sBP-BSM (0.5 mM) to check its 2-sec-butylphenol-degrading ability. The 2-sec-butylphenol completely disappeared from the sediment culture within 14 days. Enrichment culture of the sediment sample resulted in the isolation of a bacterial strain, MS-1, that could be aerobically grown on $0.5 \mathrm{mM} 2$-sec-butylphenol as the sole carbon and energy source. Strain MS-1 formed cream colonies on 2sBP-BSM $(0.5 \mathrm{mM})$ agar. The isolate was a rodshaped, gram-negative, catalase- and oxidase-positive bacterium. The isolate utilized glucose, D-mannose, gluconate, $n$-caprate, D,L-malate, citrate, and phenylacetate as sole carbon sources, but not L-arabinose, D-mannitol, $N$-acetyl-D-glucosamine, maltose, or adipate. The partial 16S rRNA gene sequence of the isolate showed the closest sequence identity $(99.0 \%)$ to Pseudomonas taiwanensis BCRC $17751^{\mathrm{T}}$ (accession 


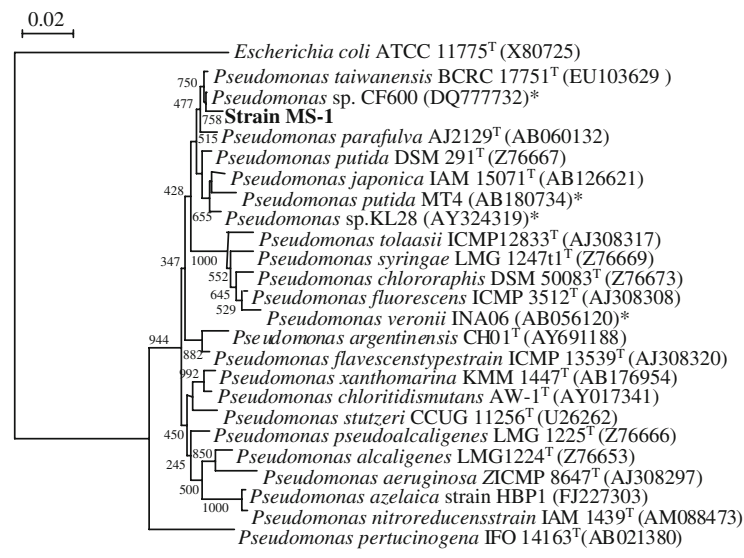

Fig. 1 Phylogenetic relationships established by the neighborjoining method, based on 16S rRNA gene sequences of strain MS-1, type strains of Pseudomonas sp., and previously isolated medium-length 4- $n$-alkylphenol-degrading (*) bacterial strains. Numbers on branches indicate bootstrap confidence estimates obtained with 1,000 replicates. Scale bar represents an evolutionary distance (Knuc) of 0.01

no. EU103629). Therefore, we identified strain MS-1 as a strain of Pseudomonas sp. Figure 1 shows the phylogenetic relationships that were established on the basis of the 16S rRNA gene sequence of strain MS-1. Figure 1 also shows closely related type strains and previously isolated alkylphenol-degrading strains. Our isolate was phylogenetically related to medium-length 4-n-alkylphenol-degrading bacteria, including Pseudomonas sp. CF600 (accession no. DQ777732), Pseudomonas putida MT4 (accession no. AB180734), and Pseudomonas sp. KL28 (accession no. AY324319).

Degradation of 2-sec-butylphenol by strain MS-1

Strain MS-1 pre-grown on 2-sec-butylphenol completely degraded $1.5 \mathrm{mM}$ 2-sec-butylphenol within $30 \mathrm{~h}$, and the bacterial cell density $\left(\mathrm{OD}_{600}\right)$ increased in parallel with 2-sec-butylphenol degradation (Fig. 2). Yield coefficient of the cells was $68.5 \mathrm{mg}$ dry weight/mmol of 2-sec-butylphenol (0.457 mg dry weight $/ \mathrm{mg}$ of 2-sec-butylphenol). 2-Methylbutyric acid was detected by GC-MS analysis after $3 \mathrm{~h}$ of cultivation, along with decrease in 2-sec-butylphyenol. Retention time and MS spectrum of 2-methylbutyric acid corresponded to those of its authentic compound. The concentration of 2-methybutyric acid increased from 3 to $21 \mathrm{~h}$ of cultivation and reached a maximum of $0.13 \mathrm{mM}$ after $21 \mathrm{~h}$ of cultivation, subsequently decreasing to an undetected level within $30 \mathrm{~h}$ (Fig. 2). In addition, strain MS-1 pre-grown on 2-sec-butylphenol rapidly and completely degraded $1.5 \mathrm{mM}$ 2-methylbutyric acid within $12 \mathrm{~h}$, with concomitant cell growth (data not shown). Yield coefficient of the cells was $39.5 \mathrm{mg}$ dry weight $/ \mathrm{mmol}$ of 2-methylbutyric acid $(0.387 \mathrm{mg}$ dry weight $/ \mathrm{mg}$ of 2-methylbutyric acid).

Identification of metabolites and 2-secbutylphenol degradation pathway

Analysis of the acetate: $n$-hexane extract with and without TMS derivatization by GC-MS showed the presence of 3-sec-butylcatechol (Fig. 3a) and its meta-cleavage product, namely, 2-hydroxy-6-oxo-7methylnona-2,4-dienoic acid (Fig. 3b). MS spectra of 3-sec-butylcatechol and 2-hydroxy-6-oxo-7-methylnona-2,4-dienoic acid corresponded to those in previous report (van der Maarel and Kohler 1993). 3sec-Butylcatechol and 2-hydroxy-6-oxo-7-methylnona-2,4-dienoic acid appeared and increased from 3 to $21 \mathrm{~h}$ of cultivation, and subsequently both metabolites completely disappeared within $30 \mathrm{~h}$.

On the basis of the metabolites identified and the results of previous study (van der Maarel and Kohler 1993), we propose a pathway for the degradation of 2-sec-butylphenol by strain MS-1 (Fig. 4). Briefly, 2sec-butylphenol is hydroxylated to 3-sec-butylcatechol. Subsequently, 3-sec-butylcatechol is metabolized to 2-hydroxy-6-oxo-7-methylnona-2,4-dienoic

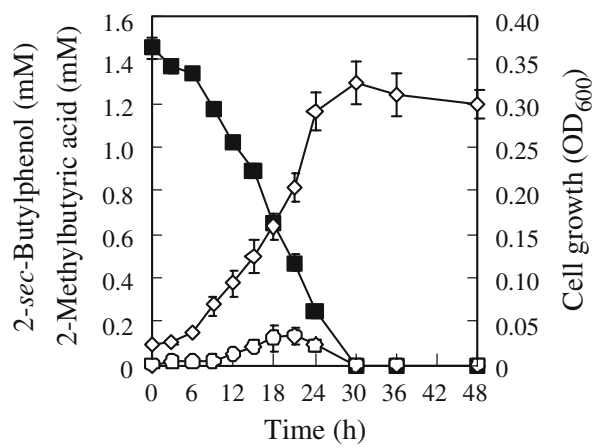

Fig. 2 Degradation of 2-sec-butylphenol and cell growth of strain MS-1 grown in basal salt medium (BSM) containing $1.5 \mathrm{mM}$ 2-sec-butylphenol. Concentrations of 2-sec-butylphenol (closed squares) and 2-methylbutyric acid (open circles), and cell densities (open diamonds) were monitored over $48 \mathrm{~h}$. Data represent the means of triplicate experiments, and error bars indicate $95 \%$ confidence intervals 
Fig. 3 Mass spectra of metabolites formed during degradation of 2-sec-

butylphenol by strain MS-1.

a Metabolite I was

identified as 3-sec-

butylcatechol. b Metabolite

II was identified as a meta-

cleavage product, namely,

2-hydroxy-6-oxo-7-

methylnona-2,4-dienoic

acid, with

trimethylsilylation (TMS)

derivatization

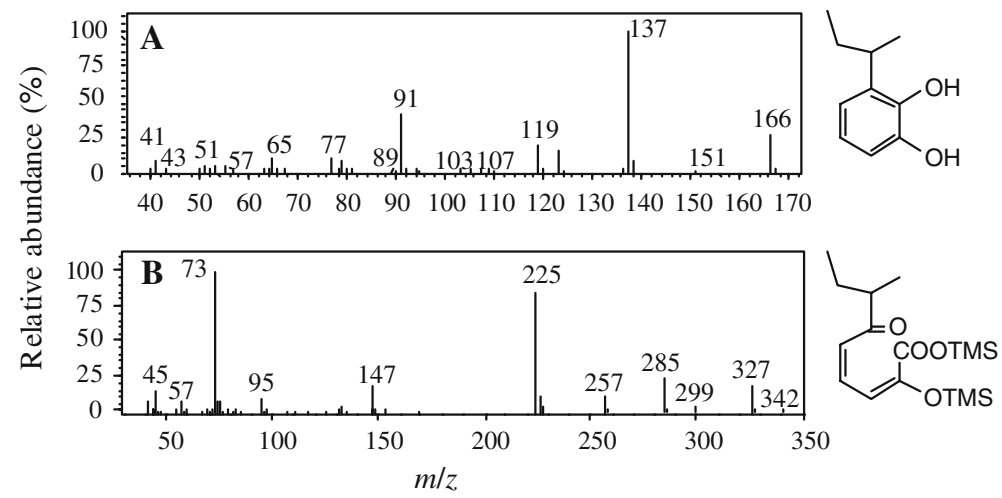

that alkylphenol degradation by MS-1 depends on the position (ortho $\gg$ meta $=$ para) of the alkyl chain and not on the branching and size of the alkyl chain.

\section{Discussion}

This study reports the isolation and characterization of an aerobic bacterium, Pseudomonas sp. strain MS-1, capable of utilizing 2-sec-butylphenol as the sole carbon and energy source. To our knowledge, strain MS-1 is the first 2-sec-butylphenol-utilizing bacterium isolated from a natural aquatic environment. Our strain MS-1 was phylogenetically related to medium-length 4-n-alkylphenol-degrading Pseudomonas strains, including strains CF600, MT4, KL28, and INA06, rather than to Pseudomonas azelaica strain HBP1 (Fig. 1).

Strain MS-1 degraded $1.5 \mathrm{mM}$ 2-sec-butylphenol within $30 \mathrm{~h}$, whereas strain HBP1 Prp can degrade $2.0 \mathrm{mM}$ 2-sec-butylphenol within $45 \mathrm{~h}$ (van der Maarel and Kohler 1993), suggesting that the rate of 2-sec-butylphenol degradation by our strain MS-1 is comparable to that by strain HBP1 Prp. Our results

Fig. 4 Proposed pathway for metabolism of 2-secbutylphenol by strain MS-1: (I) 2-sec-butylphenol; (II) 3-sec-butylcatechol; (III) 2hydroxy-6-oxo-7methylnona-2,4-dienoic acid; (IV) 2-methylbutyric acid; (V) 2-hydroxypent2,4-dienoic acid

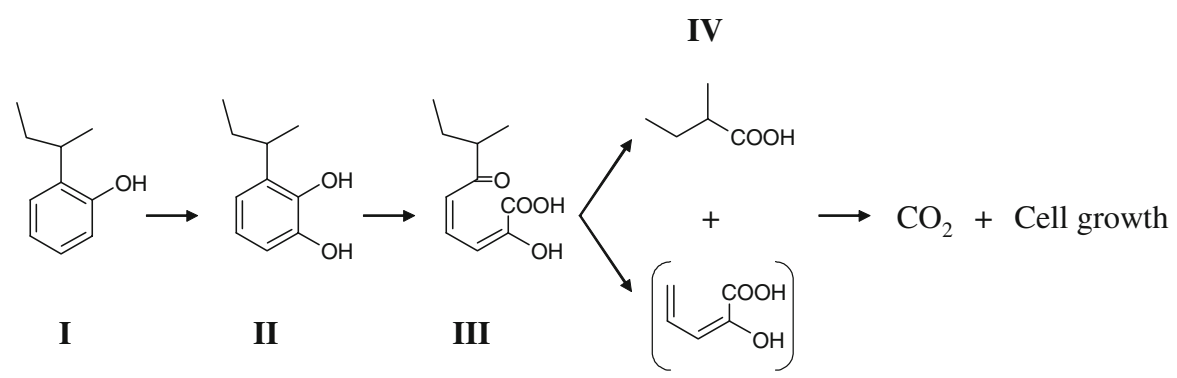


Table 1 Utilization and degradability of various alkylphenols by strain MS-1

\begin{tabular}{llll}
\hline Substrate & Structure & Growth $^{\mathrm{a}}$ & Transformation ratio $(\%)^{\mathrm{b}}$
\end{tabular}

Phenol<smiles>Oc1ccccc1</smiles>

$o$-Cresol<smiles>Cc1ccccc1O</smiles>

$m$-Cresol

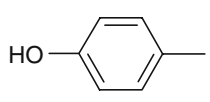

p-Cresol<smiles>Cc1cccc(O)c1</smiles>

2-Ethylphenol<smiles>CCc1ccccc1O</smiles>

3-Ethylphenol<smiles>CCc1cccc(O)c1</smiles>

4-Ethylphenol<smiles>CCc1ccc(O)cc1</smiles>

2-n-Propylphenol<smiles>CCCc1ccccc1O</smiles>

2-Isopropylphenol

$+$ 100

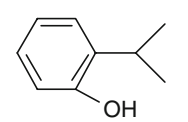


Table 1 continued

Transformation ratio $(\%)^{\mathrm{b}}$<smiles>CC(C)(C)c1ccc(O)cc1</smiles>

Substrate Structure

Growth $^{\mathrm{a}}$

3-Isopropylphenol<smiles>CC(C)c1cccc(O)c1</smiles>

4-n-Propylphenol

$-$

0<smiles>CCCc1ccc(O)cc1</smiles>

4-Isopropylphenol<smiles>CC(C)c1ccc(O)cc1</smiles>

0

2-sec-Butylphenol<smiles>CCC(C)c1ccccc1O</smiles>

2-tert-Butylphenol<smiles>CC(C)(C)c1ccccc1O</smiles>

3-tert-Butylphenol<smiles>CC(C)(C)c1cccc(O)c1</smiles>

4-n-Butylphenol<smiles>CCCCc1ccc(O)cc1</smiles>

4-sec-Butylphenol<smiles>CCC(C)c1ccc(O)cc1</smiles>

4-tert-Butylphenol

0

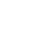

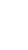

$+$

(1)$$
\text { (n) }
$$$$
-
$$

0 0 
Table 1 continued

\begin{tabular}{|c|c|c|c|}
\hline Substrate & Structure & Growth $^{\mathrm{a}}$ & Transformation ratio $(\%)^{\mathrm{b}}$ \\
\hline 2,4-Di-tert-butylphenol & & - & 0 \\
\hline 2,6-Di-tert-butylphenol & & - & 0 \\
\hline 6-tert-Butyl-m-cresol & & + & 100 \\
\hline
\end{tabular}

\footnotetext{
a " + " indicates a significant increase in cell density $\left(\mathrm{OD}_{600}\right)$ from 0.02 to $>0.05$, whereas "-" indicates no significant increase in cell density

b Transformation ratios were calculated from HPLC chromatograms obtained from 48-h cultures of strain MS-1 whole cells and autoclaved sterile controls as follows: transformation ratio $(\%)=(1-$ [peak area for substrate obtained from whole cells]/[peak area for substrate obtained from the sterile control] $) \times 100$
}

indicated that the metabolism of 2-sec-butylphenol by strain MS-1 proceeds by the same metabolic pathway as degradation of 2-sec-butylphenol by strain HBP1 Prp (van der Maarel and Kohler 1993). That is, 2-secbutylphenol is initially hydroxylated to 3-sec-butylcatechol, and 3-sec-butylcatechol is further metabolized along a meta-cleavage pathway (Fig. 4).

Our experiments show that the alkylphenol-metabolizing system in strain MS-1 has substrate specificity that depended on the position of the alkyl chain. Strain MS-1 could degrade ortho-butylphenols but not meta- and para-butylphenols. In contrast, strain MS-1 showed degradative activity for 2-alkylphenols with various sized and branched alkyl chain (methyl, ethyl, $n$-propyl, isopropyl, sec-butyl, and tert-butyl); the strain also utilized 2-alkylphenols with an alkyl chain (n-propyl, isopropyl, sec-butyl, and tert-butyl). Strain MS-1 also degraded a dialkylphenolic compound, namely, 6-tert-butyl-m-cresol and utilized it as the sole carbon source, but not 2,4-di-tert-butylphenol and 2,6-di-tert-butylphenol. Strain HBP1 Prp shows degradative activity for a variety of ortho-substituted alkylphenols with a short- or medium-length alkyl chain (o-cresol, 2-ethylphenol, 2-n-propylphenol, 2-isopropylphenol, and 2-secbutylphenol), but it shows very little activity for 2tert-butylphenol (Kohler et al. 1988, 1993). Thus, degradative range for 2-alkylphenols of strain MS-1 appears to be wider than that of strain HBP1 Prp.

Until now, nothing has been known about the bacteria that degrade ortho-substituted alkylphenols and the mechanisms of this biodegradation in the natural aquatic environment. Previously reported 4NP-degrading (Tanghe et al. 1999) and mediumlength 4-n-alkylphenol-degrading aerobic bacteria (Jeong et al. 2003; Takeo et al. 2006) cannot degrade ortho-substituted isomers. In contrast, strain MS-1 degraded a variety of alkylphenols only with orthsubstituted alkyl chain. This interesting characteristic is very different from previously reported alkylphenol degraders. Our results provide new insight into the degradation of 2-alkylphenols and will contribute to remediation of alkylphenol pollutants generally in aquatic environments. Further study to gain a more 
detailed understanding of the 2-sec-butylphenol enzymes of strain MS-1 is under way.

Acknowledgments This research was supported by a Grantin-Aid for Young Scientists (B) (no. 19710060) from the Ministry of Education, Culture, Sports, Science, and Technology of Japan.

Open Access This article is distributed under the terms of the Creative Commons Attribution Noncommercial License which permits any noncommercial use, distribution, and reproduction in any medium, provided the original author(s) and source are credited.

\section{References}

Acuña-Argüelles ME, Olguin-Lora P, Razo-Flores E (2003) Toxicity and kinetic parameters of the aerobic biodegradation of the phenol and alkylphenols by a mixed culture. Biotechnol Lett 25:559-564. doi:10.1023/A:102289832 1664

Ajithkumar B, Ajithkumar VP, Iriye R (2003) Degradation of 4-amylphenol and 4-hexylphenol by a new activated sludge isolate of Pseudomonas veronii and proposal for a new subspecies status. Res Microbiol 154:17-23. doi:10. 1016/S0923-2508(02)00009-8

Choi K, Sweet LI, Meier PG, Kim P-G (2004) Aquatic toxicity of four alkylphenols (3-tert-butylphenol, 2-isopropylphenol, 3-isopropylphenol, and 4-isopropylphenol) and their binary mixtures to microbes, invertebrates, and fish. Environ Toxicol 19:45-50

Fujii K, Urano N, Ushio H, Satomi M, Kimura S (2001) Sphingomonas cloacae sp. nov., a nonylphenol-degrading bacterium isolated from wastewater of a sewage-treatment plant in Tokyo. Int J Syst Evol Microbiol 51:603-610

Gabriel FLP, Giger W, Guenther K, Kohler H-PE (2005) Differential degradation of nonylphenol isomers by Sphingomonas xenophaga Bayram. Appl Environ Microbiol 71:1123-1129. doi:10.1128/AEM.71.3.1123-1129.2005

Hu J-Y, Aizawa T (2003) Quantitative structure-activity relationships for estrogen receptor binding affinity of phenolic chemicals. Water Res 37:1213-1222

Inoue D, Hara S, Kashihara M, Murai Y, Danzl E, Sei K, Tsunoi S, Fujita M, Ike M (2008) Degradation of bis(4-hydroxyphenyl) methane (bisphenol F) by Sphingobium yanoikuyae strain FM-2 isolated from river water. Appl Environ Microbiol 74:352-358. doi:10.1128/AEM.01708-07

Jeong JJ, Kim JH, Kim C-K, Hwang I, Lee K (2003) 3- and 4-Alkylphenol degradation pathway in Pseudomonas sp. strain KL28: genetic organization of lap gene cluster and substrate specificities of phenol hydroxylase and catechol 2,3-dioxygenase. Microbiology 149:3265-3277. doi: 10.1099/mic.0.26628-0
Kohler H-PE, Kohler-Staub D, Focht DD (1988) Degradation of 2-hydroxybiphenyl and 2,2'-dihydroxybiphenyl by Pseudomonas sp. strain HBP1. Appl Environ Microbiol 54:2683-2688

Kohler H-PE, van der Maarel MJEC, Kohler-Staub D (1993) Selection of Pseudomonas sp. strain HBP1 Prp for metabolism of 2-propylphenol and elucidation of the degradative pathway. Appl Environ Microbiol 59:860-866

Li J, Ma M, Wang Z (2008) A two-hybrid yeast assay to quantify the effects of xenobiotics on thyroid hormonemediated gene expression. Environ Toxicol Chem 27: 159-167. doi:10.1897/07-054.1

McLeese DW, Zitko V, Sergeant DB, Burridge L, Metcalfe CD (1981) Lethality and accumulation of alkylphenols in aquatic fauna. Chemosphere 10:723-730

Reichlin F, Kohler H-PE (1994) Pseudomonas sp. strain HBP1 Prp degrades 2-isopropylphenol (ortho-cumenol) via meta cleavage. Appl Environ Microbiol 60:4587-4591

Routledge EJ, Sumpter JP (1997) Structural features of alkylphenolic chemicals associated with estrogenic activity. J Biol Chem 272:3280-3288

Servos MR (1999) Review of the aquatic toxicity, estrogenic responses and bioaccumulation of alkylphenols and alkylphenol polyethoxylates. Water Qual Res J Can 34:123-177

Takeo M, Prabu SK, Kitamura C, Hirai M, Takahashi H, Kato D, Negoro S (2006) Characterization of alkylphenol degradation gene cluster in Pseudomonas putida MT4 and evidence of oxidation of alkylphenols and alkylcatechols with medium-length alkyl chain. J Biosci Bioeng 102: 352-361. doi:10.1263/jbb.102.352

Tanghe T, Dhooge W, Verstraete W (1999) Isolation of a bacterial strain able to degrade branched nonylphenol. Appl Environ Microbiol 65:746-751

Tollefsen K-E, Eikvar S, Finne EF, Fogelberg O, Gregersen IK (2008) Estrogenicity of alkylphenols and alkylated nonphenolics in a rainbow trout (Oncorhynchus mykiss) primary hepatocyte culture. Ecotoxicol Environ Saf 71:370383. doi:10.1016/j.ecoenv.2007.10.006

Toyama T, Sato Y, Inoue D, Sei K, Chang Y-C, Kikuchi S, Ike M (2009) Biodegradation of bisphenol A and bisphenol F in the rhizosphere sediment of Phragmites australis. J Biosci Bioeng 108:147-150. doi:10.1016/j.jbiosc.2009. 03.011

van der Maarel MJEC, Kohler H-PE (1993) Degradation of 2-sec-butylphenol: 3-sec-butylcatechol, 2h-hydroxy-6oxo-7-methylnona-2, 4-dienoic acid, and 2-methylbutyric acid as intermediates. Biodegradation 4:81-89

White R, Jobling S, Hoare SA, Sumpter JP, Parker MG (1994) Environmentally persistent alkylphenolic compounds are estrogenic. Endocrinology 135:175-182

Ying GG, Williams B, Kookana R (2002) Environmental fate of alkylphenols and alkylphenol ethoxylates-a review. Environ Int 28:215-226 